\title{
ANALISIS KELAYAKAN USAHA PENGOLAHAN ONGGOK (Studi Kasus di Desa Pasirpanjang Kecamatan Manonjaya Kabupaten Tasikmalaya)
}

\section{FEASIBILITY ANALYSIS OF ONGGOK PROCECESSING BUSINES (Case Study In Pasirpanjang Villagr Manonjaya District Tasikmalaya Regency)}

\author{
Randina $^{1 *}$, Iwan Setiawan ${ }^{2}$, Agus Yuniawan Isyanto ${ }^{1}$ \\ ${ }^{1}$ Fakultas Pertanian, Universitas Galuh Ciamis \\ ${ }^{2}$ Fakultas Pertanian, Universitas Padjadjawan \\ Email: randina1996@gmail.com
}

\begin{abstract}
ABSTRAK
Penelitian ini dilaksanakan bertujuan untuk menganalisis: (1) Kelayakan finansial (ekonomi), teknis, sosial dan ekologi usaha pengolahan onggok; dan (2) Laju kepekaan (sensitivitas) usaha pengolahan onggok ketika terjadi kenaikan biaya produksi terhadap kelayakan finansialnya. Penelitian dilaksanakan di Desa Pasirpanjang Kecamatan Manonjaya Kabupaten Tasikmalaya dengan menggunakan metode kualitatif dan teknik studi kasus pada satu unit usaha pengolahan onggok yang diambil secara purposive. Data didapat melalui hasil wawancara mendalam, kemudian dianalisis secara statistik deskriptif dengan menggunakan analisis kelayakan finansial dan uji sensitivitas. Hasil penelitian menunjukan bahwa usaha pengolahan onggok tersebut dinyatakan layak, dengan nilai NPV sebesar Rp. 1.799.886.000, Net B/C 1,99, Gross B/C 2,11 dan IRR 117\%. Payback periode (PP) dari investasi yang telah dikeluarkan dalam usaha pengolahan onggok tersebut adalah 1 tahun 2 bulan 13 hari.
\end{abstract}

Kata Kunci : Onggok, kelayakan finansial, analisis sensitivitas.

\section{ABSTRACT}

This research was conducted with the aim of analyzing: (1) the financial (economic), technical, social and ecological feasibility of onggok processing business; and (2) Sensitivity rate (sensitivity) of cassava processing business when there is an increase in production costs to its financial feasibility. The research was conducted in the village of Pasir Panjang, Manonjaya District, Tasikmalaya Regency, using qualitative methods and case study techniques in one unit of processing onggok which was taken purposively. Data obtained through in-depth interviews were then analyzed statistically descriptively using financial feasibility analysis and sensitivity testing. The results showed that the onggok processing business was declared feasible, with an NPV value of Rp. 1,799,886,000, Net B / C 1.99, Gross B / C 2.11 and IRR 117\%. The payback period (PP) of the investment that has been spent in the onggok processing business is 1 year 2 months 13 days.

Keywords: Onggok, financial feasibility, sensitivity analysis.

\section{PENDAHULUAN}

Singkong atau yang sering disebut ubi kayu adalah tanaman pangan yang potensial karena banyak mengandung karbohidrat sehingga sering dijadikan sebagai makanan pokok. Selain banyak mengandung karbohidrat, ubi kayu ini juga terdapat unsur-unsur lain seperti air sekitar sebanyak $60 \%$, pati sebanyak $25-35 \%$, protein, serat kalsium, serta fosfat (Elfandari, 2008) 
Di dalam daerah yang iklimnya tropis dan subtropis tanaman ini dapat tumbuh dengan baik, sehingga para petani banyak yang membudidayakan tanaman ini untuk dikomersilkan. Di Indonesia tanaman ubi kayu ini hampir sudah menyebar luas, di tiap daerah nama ubi kayu ini berbeda-beda, di antaranya adalah ketela pohon, singkong, telo puhung, kasape, bodin, sampeu, huwi dangdeur, huwi jenderal, kasbek, kikim, dan lain-lain (Najiyati dan Danarti, 2000).

Ubi kayu adalah tanaman yang berasal dari negara Brazil. Tanaman ini pertama kali ada di Indonesia sekitar tahun
1852 di Kebun Raya Bogor. Memasyarakatnya singkong di kalangan petani disebabkan oleh dua hal, pertama tanaman singkong mudah dibudidayakan, dan kedua singkong mengandung karbohidrat tinggi, sehingga dapat digunakan oleh masyarakat sebagai pengganti beras untuk menjadi bahan makanan (Najiyati dan Danarti 2000).

Produksi singkong di Kabupaten Tasikmalaya diolah menjadi tepung tapioka. Terdapat 12 agroindustri yang mengolah singkong menjadi tepung tapioka pada enam kecamatan di Kabupaten Tasikmalaya (Tabel 1). 
Tabel 1. Sebaran Agroindustri Tapioka di Kabupaten Tasikmalaya

\begin{tabular}{|c|c|c|c|c|c|}
\hline No. & $\begin{array}{c}\text { Nama } \\
\text { Perusahaan }\end{array}$ & Alamat & $\begin{array}{c}\text { Kapasitas } \\
\text { Produksi } \\
\text { (Ton/Bulan) }\end{array}$ & $\begin{array}{l}\text { Nilai Investasi } \\
\quad \text { (Rp 000) }\end{array}$ & $\begin{array}{l}\text { Tenaga Kerja } \\
\text { (Orang) }\end{array}$ \\
\hline 1. & $\begin{array}{l}\text { Karya Subur } \\
\text { Sentosa }\end{array}$ & $\begin{array}{l}\text { Ds. Cilangkap } \\
\text { Kec. Manonjaya }\end{array}$ & 12.000 & 54.800 & 26 \\
\hline 2. & Cahaya Utama & $\begin{array}{l}\text { Ds. Pasirpanjang } \\
\text { Kec. Manonjaya }\end{array}$ & 480 & 27.500 & 5 \\
\hline 3. & Karta & $\begin{array}{l}\text { Ds. Cijulang } \\
\text { Kec. Cineam }\end{array}$ & 200 & 8.500 & 5 \\
\hline 4. & Harun. S.Pd. & $\begin{array}{l}\text { Ds. Cikondang } \\
\text { Kec. Cineam }\end{array}$ & 200 & 15.000 & 5 \\
\hline 5. & Tatang D.H & $\begin{array}{l}\text { Ds. Nagaratengah } \\
\text { Kec. Cineam }\end{array}$ & 250 & 25.000 & 12 \\
\hline 6. & G.N & $\begin{array}{l}\text { Ds. Cijulang } \\
\text { Kec. Cineam }\end{array}$ & 60 & 14.600 & 3 \\
\hline 7. & Cahaya Murni & $\begin{array}{l}\text { Ds. Cikondang } \\
\text { Kec. Cineam }\end{array}$ & 3,75 & 18.500 & 10 \\
\hline 8. & Jembar Rahayu & $\begin{array}{l}\text { Ds. Guranteng } \\
\text { Kec. Pagerageung }\end{array}$ & 280 & 46.500 & 5 \\
\hline 9. & Aneka Jaya & $\begin{array}{l}\text { Ds. Kartarahayu } \\
\text { Kec. Jatiwaras }\end{array}$ & 30 & 23.000 & 7 \\
\hline 10. & $\begin{array}{l}\text { Perusahaan Aci } \\
\text { Singkup }\end{array}$ & $\begin{array}{l}\text { Ds. Setiawangi } \\
\text { Kec. Jatiwaras }\end{array}$ & 845 & 20.000 & 8 \\
\hline 11. & $\begin{array}{l}\text { Pabrik Aci } \\
\text { Cinunjang }\end{array}$ & $\begin{array}{c}\text { Ds. Cinunjang } \\
\text { Kec. Gunungtanjung }\end{array}$ & 240 & 6.000 & 15 \\
\hline 12. & Aci Cibeureum & $\begin{array}{l}\text { Ds. Sirna Jaya } \\
\text { Kec. Sukaraja }\end{array}$ & 2.100 & 100.000 & 61 \\
\hline
\end{tabular}

Sumber: Dinas Perindustrian Kabupaten Tasikmalaya 2020

Tabel 1 menunjukkan bahwa agroindustri di Kecamatan Manonjaya menghasilkan produksi tepung tapioka sebanyak 480 ton/bulan. Perusahaan yang paling banyak menghasilkan tepung tapioka yaitu perusahaan Karya Subur Sentosa sebanyak 12.000 ton/bulan.

Agroindustri tepung tapioka selain menghasilkan tepung tapioka, juga menghasilkan limbah padat yang disebut onggok. Dari setiap ton singkong menghasilkan sekitar $250 \mathrm{~kg}$ tapioka dan
$114 \mathrm{~kg}$ onggok. Onggok juga dapat dijadikan sebagai pakan ternak ruminansia,bahan saus, namun perlu dilakukan pengolahan lebih lanjut (Muhtarudin, 2012). Berdasarkan uraian di atas, maka penulis tertarik untuk melaksanakan penelitian mengenai "Analisis Kelayakan Usaha Pengolahan Onggok di Desa Pasirpanjang Kecamatan Manonjaya Kabupaten Tasikmalaya". 


\section{Identifikasi Masalah}

Adapun identifikasi masalah dari masalah ini sebagai berikut:

1. Bagaimana kelayakan finansial usaha pengolahan onggok di Desa Pasirpanjang Kecamatan Manonjaya Kabupaten Tasikmalaya ?

2. Bagaimana laju kepekaan (sensitivitas) usaha pengolahan onggok di Desa Pasirpanjang Kecamatan Manonjaya Kabupaten Tasikmalaya jika terjadi kenaikan biaya produksi, terhadap kelayakan finansialnya ?

\section{Tujuan Penelitian}

Adapun Penelitian ini bertujuan untuk menganalisis:

1. Kelayakan finansial usaha pengolahan onggok di Desa Pasirpanjang Kecamatan Manonjaya Kabupaten Tasikmalaya.

2. Laju kepekaan (sensitivitas) usaha pengolahan onggok di Desa Pasirpanjang Kecamatan Manonjaya Kabupaten Tasikmalaya jika terjadi kenaikan biaya produksi terhadap kelayakan finansialnya.

\section{Kegunaan Penelitian}

Hasil dari penelitian ini diharapkan bisa memberikan kegunaan bagi:
1. Peneliti, sebagai tambahan informasi mengenai kelayakan finansial usaha pengolahan onggok.

2. Pelaku usaha, sebagai informasi dan pertimbangan dalam pengambilan keputusan yang berkaitan dengan usahanya.

3. Peneliti lain, sebagai referensi dalam melaksanakan penelitian selanjutnya.

\section{METODE PENELITIAN}

Penelitian ini dilakukan dengan menggunakan metode kualitatif dan teknik studi kasus pada satu unit usaha pengolahan onggok di Desa Pasirpanjang Kecamatan Manonjaya Kabupaten Tasikmalaya.

Data dalam penelitian ini menggunakan data primer dan sekunder. Data primer diperoleh dengan cara pengamatan langsung di lokasi penelitian dan wawancara dengan responden dengan menggunakan daftar pertanyaan yang telah disusun sesuai dengan tujuan penelitian.Sedangkan data sekunder didapat dari hasil penelusuran referensi maupun publikasi dari dinas/instansi terkait.

Sampel yang diambil dalam proses penelitian yaitu perusahaan Cahaya Utama di Desa Pasirpanjang Kecamatan Manonjaya Kabupaten Tasikmalaya yang diambil secara sengaja (purposive 
sampling) dengan pertimbangan merupakan satu-satunya perusahaan yang mengolah onggok menjadi tepung.

Penelitian ini dilaksanakan di Desa Pasirpanjang Kecamatan Manonjaya Kabupaten Tasikmalaya.

Data yang diperoleh dianalisis dengan menggunakan metode analisis kelayakan finansial. Untuk lebih jelasnya kelayakan finansial usaha pengolahan onggok di Desa Pasirpanjang Kecamatan Manonjaya Kabupaten Tasikmalaya digunakan metodemetode menurut Husnan dan Muhammad (2005):

\section{Analisis Kelayakan}

\section{Net Present Value (NPV). Net Present} Value $(N P V)$ adalah selisih antara hasil dari penerimaan dengan biaya yang telah di-present value-kan. Dalam kriteria ini dikatakan bahwa suatu proyek yang dipilih apabila nilai dari NPV nya lebih besar dari nol. Menurut Husnan dan muhammad (2005), NPV adalah nilai saat ini dari arus manfaat yang ditimbulkan oleh penanaman modal awal. Rumus yang akan digunakan adalah:

$$
\mathrm{NPV}=\sum_{\mathrm{t}=0}^{\mathrm{n}} \quad \frac{\mathrm{Bt}-\mathrm{Ct}}{(1+\mathrm{i})^{\mathrm{t}}}
$$

Keterangan:
$\mathrm{Bt}=$ Benefit (penerimaan usaha pada tahun ke-t)

$\mathrm{Ct}=$ Cost (biaya usaha pada tahun ke-t)

$\mathrm{n}=$ Umur ekonomis suatu proyek

$\mathrm{i}=$ Tingkat suku bunga yang berlaku Kriteria investasi berdasarkan

NPV adalah: NPV > 0, maka usaha tersebut menguntungkan dan dapat dilaksanakan.

NPV $=0$, maka proyek tidak untung dan tidak rugi (proyek dapat mengembalikan modal).

NPV < 0, maka usaha ini merugikan karena hasil yang didapat lebih kecil dibandingkan dengan biaya yang dikeluarkan, lebih baik usaha tersebut tidak dijalankan.

2. Net B/C (Net Benefit Cost Ratio). Usaha Pengolahan Onggok dapat dikatakan menguntungkan (profitable) apabila nilai Net $B / C>1$. Rumus yang dapat mengetahui $\mathrm{Net} B / C$ menurut Husnan dan Muhammad (2005) sebagai berikut:

$$
\sum \text { (NPVpositif) }
$$

Net $B / C={ }^{t=1}$

$$
\sum_{t=1}(\text { NPVNegatiff })
$$

Keterangan:

$\mathrm{Bt}=$ Benefit (hasil penerimaan kotor pada tahun ke-t)

$\mathrm{Ct}=$ Cost (biaya kotor pada tahun ke-t)

$\mathrm{n}=$ umur ekonomis suatu usaha

$\mathrm{i}=$ tingkat suku bunga 
3. Gross B/C (Gross Benefit Cost Ratio). Gross Benefit Cost Ratio (Gross B/C) adalah perhitungan untuk mengetahui tingkat perbandingan antara hasil dari penerimaan kotor dengan jumlah biaya kotor yang diperhitungkan nilainya saat ini, dengan rumus sebagai berikut:

Gross B/C

$$
=\frac{P V \text { dari gross benefits }}{P V \text { dari gross costs }}
$$

\section{Internal Rate of Return (IRR). Kriteria} yang menunjukkan bahwa suatu usaha layak dijalankan adalah jika IRR nya lebih besar dari tingkat suku bunga yang berlaku pada saat usaha tersebut diusahakan. Menurut Husnan dan Muhamad (2005) rumus yang bisa digunakan untuk mencari IRR adalah:

$$
I R R=i_{1} \frac{N P V_{1}}{\left(N P V_{1}-N P V_{2}\right)}\left(i_{2}-i_{1}\right)
$$

Keterangan:

$\mathrm{NPV}_{1}=\mathrm{NPV}$ yang nilainya positif .

$\mathrm{NPV}_{2}=\mathrm{NPV}$ yang bernilai negatif.

$\mathrm{i}_{1}=$ tingkat suku bunga saat menghasilkan NPV yang bernilai positif.

$\mathrm{i}_{2}=$ tingkat suku bunga saat menghasilkan NPV yang bernilai negatif.

5. Analisis Payback Period. Payback perod (PP) adalah jangka waktu atau periode yang diperlukan suatu perusahaan untuk membayar kembali semua biaya yang telah dikeluarkan.

\section{Analisis Sensitivitas}

Analisis sensitivitas bertujuan untuk melihat yang akan terjadi dengan analisis usaha tersebut jika terjadi kesalahan atau perubahan pada perhitungan biaya atau benefit (Djamin, 1992).

Dalam analisis kepekaan ini, kemungkinan harus dicoba untuk dilaksanakan analisa kembali. Hal ini perlu, karena setiap analisis proyek biasanya didasarkan pada proyeksi-proyeksi yang mengandung banyak ketidakpastian dan perubahan yang akan terjadi masa yang akan datang.

Dalam pelaksanaan suatu usaha, penerimaan dan biaya dapat mempengaruhi besarnya nilai NPV, Net B/C, Gross B/C, dan IRR. Perubahan nilai NPV, Net B/C, Gross B/C, dan IRR dapat terjadi karena terdapat perubahan dalam dasar-dasar perhitungan biaya dan manfaat.

Dalam penelitian ini, analisis sensitivitas dilaksanakan pada arus penerimaan dan pengeluaran. Adapun perubahan-perubahan yang akan dikaji pada analisis sensitivitas adalah naiknya biaya produksi yang telah terjadi dan batas kelayakan produksi.

Analisis sensitivitas dilaksanakan dengan cara menghitung salah satu 
kemungkinan diatas terjadi. Tingkat kenaikan biaya suatu produksi yang akan menyebabkan nilai NPV, Net B/C, Gross B/C, dan IRR tidak lagi akan menguntungkan, maka pada titik itulah usaha tersebut disebut tidak layak. Selain itu, perlu juga dihitung dalam setiap penurunan harga jual suatu produk jadi terhadap keuntungan yang diperoleh.

Tingkat turunnya harga jual suatu produk jadi yang akan menyebabkan nilai NPV, Net B/C, Gross B/C, dan IRR tidak meyakinkan, maka itulah batas kelayakan proyek. Jika perbedaan itu sangat kecil atau tidak berarti mengubah keputusan, maka perkiraan pendapatan dianggap "kuat" dan tidak peka terhadap perubahan dalam asumsi inflasi, karena baik rencana alternatif dan skenario didasarkan pada perkiraan.

Gittinger (1993) menyatakan bahwa dalam bidang pertanian, proyek sensitif untuk berubah, yang diakibatkan oleh empat masalah utama, yaitu:

1. Harga, terutama harga pasar yang menyebabkan perubahan turunnya harga hasil produksi..

2. Keterlambatan pelaksanaan proyek. Dalam proyek pertanian dapat terjadi keterlambatan pelaksanaanya karena ada kesulitan-kesulitan secara teknis atau inovasi baru yang diterapkan, atau keterlambatan dalam pemesanan dan penerimaan peralatan.

3. Kenaikan biaya, perhitungan terlalu rendah mengakibatkan dalam biaya konstruksi maupun biaya operasional.

4. Kenaikan hasil, dalam hal ini kesalahan perhitungan hasil.

Menghitung laju kepekaan dengan rumus sebagai berikut:

$$
\text { Laju kepekaan }=\frac{\frac{\left(X_{1}-X_{0}\right)}{\bar{X}}}{\frac{\left(Y_{1}-Y_{0}\right)}{\bar{Y}}} \times 100 \%
$$

Keterangan :

$\mathrm{X} 1=\mathrm{NPV} /$ Net $\mathrm{B} / \mathrm{C} /$ Gross B/C/IRR setelah perubahan

$\mathrm{Xo}=\mathrm{NPV} /$ Net $\mathrm{B} / \mathrm{C} /$ Gross $\mathrm{B} / \mathrm{C} / \mathrm{IRR}$ sebelum perubahan

$\overline{\mathrm{X}}=$ rata-rata perubahan NPV/Net B/C/Gross B/C/IRR

Y1=biaya produksi setelah perubahan

Yo=biaya produksi sebelum perubahan

$\overline{\mathrm{Y}}=$ rata-rata perubahan biaya produksi/harga jual/ suku bunga

Kriteria laju kepekaan:

1. Jika laju kepekaan > 1, maka hasil kegiatan usaha peka/sensitif terhadap perubahan.

2. Jika laju kepekaan $<1$, maka hasil kegiatan usaha tidak peka/sensitif terhadap perubahan. 
HASIL DAN PEMBAHASAN

Analisis Kelayakan

Nilai NPV, Net B/C dan IRR

\begin{tabular}{cll}
\hline No. & \multicolumn{1}{c}{ Uraian } & \multicolumn{1}{c}{ Nilai } \\
\hline 1 & NPV & 1.799 .886 .000 \\
2 & Net B/C & 1.99 \\
3 & IRR & $117 \%$ \\
\hline
\end{tabular}

Suatu usaha dikatakan layak menguntungkan jika nilai NPV usaha tersebut lebih besar dari $0(\mathrm{NPV}>0)$. Tabel diatas menunjukan bahwa nilai dari NPV lebih besar dari 0 yaitu 1.799.886.000 pada tingkat bunga $12 \%$. Maka dapat disimpulkan bahwa usaha pengolahan onggok di Desa Pasirpanjang menguntungkan dan layak diusahakan.

Ditinjau dari Net B/C usaha dikatakan layak bila nilai Net B/C lebih besar dari 1 (Net B/C >1), berdasarkan Tabel nilai Net $\mathrm{B} / \mathrm{C}$ sebesar 1.99. Disimpulkan bahwa usaha pengolahan onggok di Desa Pasirpanjang Kecamatan Manonjaya Kabupaten Tasikmalaya layak untuk diteruskan.

Berdasarkan tabel bahwa nilai IRR sebesar $117 \%$, hal ini menunjukan bahwa usaha pengolahan onggok di Desa Pasirpanjang Kecamatan Manonjaya Kabupaten Tasikmalaya layak untuk diteruskan,karena nilainya lebih besar dari
SOCC (Social Opportunity Cost of Capital) yaitu sebesar $12 \%$.

\section{Gross Benefit Cost Ratio (Gross B/C)}

Gross Benefit Cost Ratio (Gross B/C) merupakan perbandingan antara penerimaan kotor yang telah di discount dengan cost secara keseluruhan yang telah di discount. Hasil analisis menunjukan bahwa nilai (Gross B/C) usaha pengolahan onggok dengan discount rate $12 \%$ persen adalah 2,11 nilai tersebut menunjukan bahwa usaha pengolahan onggok layak untuk di usahakan karena lebih dari satu. Menurut Soetriono (2006) Gross B/C> 1 (satu) berarti usaha tersebut layak dikerjakan.

\section{Payback Periods}

Payback periods diartikan sebagai jangka waktu untuk pengembalian modal yang sudah diinvestasikan dari suatu proyek, melalui keuntungan yang diperoleh dari suatu proyek. Perhitungan payback period dilakukan dengan menghitung net benefit kumulatif karena benefit yang dihasilkan dalam kegiatan proyek usahatani tidak sama untuk setiap tahunnya. Jangka waktu untuk kembali nya modal yang di investasikan oleh Bapak H. Anang Suryana dalam kegiatan usaha pengolahan onggok 1 Tahun 2 Bulan 13 Hari. 


\section{Analisis Sensitivitas}

Berdasarkan hasil analisis Jika terjadi kenaikan biaya produksi naik 5\% dengan harga jual tetap, diketahui bahwa nilai NPV pada tingkat diskonto $12 \%$ yang memberikan keuntungan $\mathrm{Rp}$ 475.287.800 selama 5 tahun umur proyek, Net B/C yang diperoleh 1,26, Gross B/C yang diperoleh 2,02, IRR yang diperoleh $-102 \%$. Hasil analisis PP diatas dapat dijelaskan bahwa masa pengembalian investasinya yaitu 1 Tahun 7 Bulan 4 Hari.

\section{Hasil Analisis Sensitivitas Kenaikan Biaya Produksi 5\%}

\begin{tabular}{|c|c|c|c|c|}
\hline No & Alat Analisis & $\mathbf{H a}$ & il Analisis & Keterangan \\
\hline 1 & NPV & & 475.287 .800 & Layak \\
\hline 2 & Net B/C & & 1,26 & Layak \\
\hline 3 & Gross B/C & & 2.02 & Layak \\
\hline 4 & IRR & & $-102 \%$ & Tidak Layak \\
\hline 5 & PP & 1 & Tahun 7 Bulan 4 Hari & \\
\hline
\end{tabular}

\section{Biaya Investasi}

Biaya investasi adalah pengeluaran atau modal yang dikeluarkan sebelum proses produksi berjalan. Biaya investasi yang dikeluarkan perusahaan pengolahan onggok ini sebesar Rp. 1.806.200.000,untuk pembelian lahan pembangunan pabrik, perijinan usaha, pembelian alat yaitu berupa mesin dan penunjang lainnya.

Biaya investasi yang paling besar dikeluarkan oleh perusahaan pengolahan onggok yaitu berupa pembelian mesin penghalus sebesar Rp. 500.000.000,- dan pendirian pabrik dengan pembelian kendaraan seharga Rp. 350.000.000,- dan ijin usaha dengan pembelian lahan dengan harga masing masing sebesar $\mathrm{Rp}$.
300.000.000,-. Lalu membeli mesin jahit karung sebanyak 3 unit seharga Rp. 4.500.000.-,Timbangan seharga Rp. 1.000.000.-,Kalkulator sebanyak 2 buah seharga Rp. 100.000.-, dan membeli lampu sebanyak 10 dengan jumlah harga sebesar Rp. 200.000.-.

\section{Biaya Operasional}

Biaya operasional yaitu biaya yang dikeluarkan perusahaan pada saat proses produksi berlangsung. Biaya operasional ini berupa pajak lahan, pembelian lahan baku, pajak usaha yang dikeluarkan tiap tiga tahun sekali, pembayaran listrik, biaya tenaga kerja, transportasi, bahan bakar, dan pembelian alat-alat penunjang lain yang 
digunakan pada saat proses produksi berlangsung.

Pada awal produksi yaitu pada tahun pertama, biaya yang dikeluarkan yaitu Rp. 750.400.000,- sampai tahun ke-5 akumulasi jumlah seluruh biaya operasional yaitu sebesar Rp. 3.743.000.000,- dengan ratarata biaya operasional tiap tahunnya sebesar Rp. 748.600.000,--

Biaya operasional ini memiliki kekhasan tersendiri yaitu memilkiumur ekonomis, artinya biaya ini dikeluarkan tidak setiap ketika proses produksi berlangsung, tetapi dikeluarkannya hanya pada waktu tertentu.

\section{Benefit (Penerimaan)}

Benefit (penerimaan) adalah hasil perkalian anatar volume produksi dengan harga jual. Dari tahun ketahun jumlah benefit yang diperoleh di perusahan pengolahan onggok di Desa Pasirpanjang Kecamatan Manonjaya Kabupaten Tasikmalaya tidak mengalami penurunan tetapi cenderung meningkat, dengan total benefit dari tahun pertama sampai tahun ke5 yaitu Rp. 11.250.000.000,- dengan ratarata benefit tiap tahunnya yaitu $\mathrm{Rp}$., 2.250.000.000-.

\section{Net Benefit (Pendapatan)}

Net benefit (pendapatan) merupakan selisih dari penerimaan (benefit) dengan seluruh biaya yang dikeluarkan. Dari tahun ketahun jumlah net benefit yang diperoleh di perusahaan pengolahan onggok di Desa Pasirpanjang mengalami fluktuasi, hal ini seiring dengan jumlah biaya operasional yang dikeluarkan tiap tahun yang tidak menentu, tetapi penerimaan yang didapat tidak mengalami kenaikan yang signifikan.

Jumlah total net benefit dari tahun pertama sampai tahun ke-5 yaitu Rp. 7.507.000.000,- dengan rata-rata net benefit tiap tahunnya yaitu sebesar Rp. Rp1.501.400.000,--

\section{KESIMPULAN DAN SARAN \\ Kesimpulan}

Berdasarkan hasil penelitian dan pembahasan, maka dapat disimpulkan sebagai berikut:

1. Usaha pengolahan onggok di Desa Pasirpanjang Kecamatan Manonjaya Kabupaten Tasikmalaya secara finansial layak untuk diteruskan. Berdasarkan hasil perhitungan didapat nilai $\mathrm{NPV}=$ 1.799.886.000, Net $\mathrm{B} / \mathrm{C}=1,99$, Gross $\mathrm{B} / \mathrm{C}=2,11, \mathrm{IRR}=117 \%$ dan $\mathrm{PP}=1$ Tahun 2 Bulan 13 Hari.

2. Hasil analisis sensitivitas dapat disimpulkan bahwa jika terjadinya kenaikan biaya produksi sebesar 5\% maka didapat nilai $\mathrm{NPV}=475.287 .800$, 
Net $B / C=1,26$, Gross B/C= 2,02, IRR=102\%dan PP= 1 Tahun 7 Bulan 4 Hari.

\section{Saran}

Diharapkan kepada pemilik usaha pengolahan onggok untuk bisa menambah mesin penghalusnya, sehingga bisa menambah pendapatan ataupun keuntungan yang didapatkan semakin besar dan berlipat ganda dari investasi yang ditanamkan.

\section{DAFTAR PUSTAKA}

Dinas Perindustrian dan Perdagangan Kabupaten Tasikmalaya. 2020. UKMK di Kabupaten Tasikmalaya. Tasikmalaya.

Djamin, Z. 1992. Perencanaan dan Analisa Proyek. Fakultas Ekonomi Universitas Indonesia. Jakarta.

Elfandari, H. 2008. Pengaruh Pemberian Berbagai Konsentrasi IBA dan Jumlah Stek Buku Terhadap Perakaran Stek Batang Mini Tanaman Ubikayu (Manihot esculenta Crantz). Skripsi. Universitas Lampung. Bandar Lampung.

Gittinger, J. P. 1993. Analisa Proyekproyek pertanian. Jakarta: UI Press.

Oktaviyanti, H., Soetoro, dan Pardani, C. 2016. Analisis Kelayakan Finansial Pada Agroindustri Tempe. Jurnal Ilmiah Mahasiswa Agroinfo Galuh, 2(3): 181-188.

Herlianto, Didit dan Pujiastuti, T. 2009. Studi Kelayakan Bisnis. Yogyakarta: Graha Ilmu.
Husnan, S. dan Muhamad, S. 2005. Studi Kelayakan Proyek. Yogjakarta; UPP AMP YKPN.

Iban Sofyan. 2003, Studi Kelayakan Bisnis. Yogyakarta: Graha Ilmu.

Ibrahim, H.M.Y. 2009. Studi Kelayakan Bisnis. Jakarta: Rineka Cipta.

Jumingan. 2009. Studi Kelayakan Bisnis: Teori dan Pembuatan Proposal Kelayakan. Jakarta: Bumi Aksara.

Kadariah. 2001. Evaluasi Proyek: Analisis Ekonomi. Jakarta: LPPM Universitas Indonesia.

Kasmir dan Jakfar. 2012. Studi Kelayakan Bisnis. Cetakan ke Delapan. Jakarta: Kencana.

Kuncoro. 2002. Manajemen Perbankan, Teori dan Aolikasi. Jakarta: PT. Indeks Kelompok Gramedia.

Kurniadi, T. 2010. Kompolimerasi Grafting Monomer Asam Akrilat Pada Onggok Singkong dan Karakteristiknya. Skripsi. Institut Pertanian Bogor. Bogor.

Najiyati, Sri dan Danarti. 2000. Palawija Budidaya dan Analisis Usahatani. Jakarta: Penebar Swadaya.

Nazir, M. 2011. Metode Penelitian. Bogor: Penerbit Ghalia Indonesia.

Muhtarudin. 2012. Pemanfaatan limbah Agroindustri Untuk Ransum Ruminansia.

Lembaga Penelitian Universitas Lampung. Lampung.

Mujiningsih, MI. 2013. Analisis Kelayakan Usaha dan Strategi Pengembangan Industri Kecil di Kecamatan Matesih Kabupaten Karanganyar. Skripsi. Universitas Negeri Semarang. 
Semarang.

Primasari, E. 2016. Analisis Kelayakan Finansial Usaha Pembesaran Ikan Lele dan Ikan Mas di Kecamatan Pagelaran Kabupaten Pringsewu. Skripsi. Universitas Lampung. Bandar Lampung.

Purwono. 2009. Tanaman Ubi Kayu. http:www.psychologymania.com.

Diakses 5 April 2020.

Sari, M., Warji, Novita, D.D. dan Tamrin. 2013. Mempelajari Karakteristik Tepung Onggok pada Tiga Metode Pengeringan yang Berbeda. Jurnal Teknik Pertanian Lampung, 2(1): 43 48.
Thamrin, M. 2013. Analisis Usahatani Ubi Kayu. Skripsi. Fakultas Pertanian UMSU. Medan.

Todaro, Michael. P. 2000. Pembangunan Ekonomi di Dunia Ketiga. Edisi Ketujuh,Terjemahan Garis Munandar. Jakarta : Penerbit Erlangga

Wargiono, J., Hasanudin dan Suyanto. 2006. Teknologi Produksi Ubi kayu Mendukung. Industri Bioetanol. Jakarta: Badan penelitian dan Pengembangan Pertanian

Wirosuharjo. 2004. Dasar-dasar Demografi. Jakarta : Fakultas Ekonomi Universitas Indonesia. 